\title{
Responses of 36- to 63-day-old BUT Big 6 turkey toms to graded dietary methionine+cysteine levels
}

\author{
A. Lemme ${ }^{1}$, K. Kozłowski ${ }^{2}$, J. Jankowski ${ }^{2,4}$, A. Petri ${ }^{1}$ \\ and Z. Zduńczyk ${ }^{3}$ \\ ${ }^{1}$ Degussa AG, Feed Additives, Animal Nutrition Services \\ Rodenbacher Chaussee 4, 63457 Hanau, Germany \\ ${ }^{2}$ Department of Poultry Science, University of Warmia and Mazury in Olsztyn \\ Oczapowskiego 2, 10-957 Olsztyn, Poland \\ ${ }^{3}$ Institute of Animal Reproduction and Food Research, Polish Academy of Sciences \\ Tuwima 10, 10-747 Olsztyn, Poland
}

\begin{abstract}
A total of 734 male 36-day-old BUT Big 6 turkeys were allotted to 6 groups with 6 replicates each and were fed diets supplemented with graded methionine levels of $0,0.4,0.8,1.3,1.8$, or $2.4 \mathrm{~g} / \mathrm{kg}$, respectively. During four weeks of experimental feeding the weight gain of turkeys was proportional to the contents of methionine+cysteine in diets and consistent with the non-linear regression equation $\mathrm{Y}=3279+363 \times\left(1-\mathrm{d}^{(-12.33 \times(\mathrm{X}-0.607))}\right), \mathrm{r}^{2}=0.99$. Nitrogen retention of the turkeys indicated a trend towards an increase in the amount of retained nitrogen with increasing methionine + cysteine level. The weight gain response suggested that optimum dietary methionine+cysteine levels are higher than $0.80 \mathrm{~g} / \mathrm{MJ} \mathrm{ME}$, while feed conversion was not affected.
\end{abstract}

KEY WORDS: methionine, cysteine, growth performance, nitrogen retention, turkey

\section{INTRODUCTION}

In turkey nutrition, methionine is considered the second limiting amino acid after lysine. Dose-response data for this amino acid are scarce and current recommendations vary substantially from $0.63 \mathrm{~g} / \mathrm{MJ} \mathrm{ME}$ (GfE, 2004) to 0.94 $\mathrm{g} / \mathrm{MJ}$ ME (BUT, 2000). A question about the proper dietary methionine+cysteine level arises. Therefore, a dose-response study with 36- to 63-day-old BUT Big 6 turkey toms was conducted in order to investigate the response of the birds to graded methionine+cysteine levels.

\footnotetext{
${ }^{4}$ Corresponding author: e-mail: janj@uwm.edu.pl
} 


\section{MATERIAL AND METHODS}

A total of 734 male BUT Big 6 turkeys aged 36 days were distributed to 36 floor pens and assigned to 6 dietary treatments with 6 replicates each $\left(1.3 \mathrm{toms} / \mathrm{m}^{2}\right)$. The average initial body weight of the turkeys was $1322 \mathrm{~g}$. From day 1 to 35 all of the birds were fed commercial feeds. The experimental design comprised six dietary treatments including a methionine+cysteine deficient basal diet and 5 graded methionine+cysteine levels that were achieved by supplementing DL-Methionine. The diet was formulated to meet or exceed Degussa recommendations (2002) in order to avoid partial deficiencies for other amino acids and energy and thus to allow for a reasonable response to graded methionine+cysteine levels. The diet contained, in g/kg: 245 crude protein, $15.8 \mathrm{Lys}, 10 \mathrm{Thr}, 7.5$ methionine + cysteine and $12.36 \mathrm{MJ} \mathrm{ME} / \mathrm{kg}$. To achieve graded methionine+cysteine levels either 0, 0.4, $0.8,1.3,1.8$, and $2.4 \mathrm{~g} / \mathrm{kg}$ DL-methionine were supplemented. Amino acid and crude nutrient contents were verified by analyses.

Body weights and feed consumption were measured from day 36 to 63, weight gain (BWG) and feed conversion (FCR) were calculated.

Parallel to the growth experiment, a N-balance study was carried out. Twentyfour turkey toms were individually penned in metabolism crates. Each dietary treatment was repeated four times. After an adaptation period of 3 days excreta were quantitatively collected for 6 days. Nitrogen was determined in feed and excreta and was related to feed intake and excreta quantities in order to calculate nitrogen retention.

Data were analysed by ANOVA and a multiple range test (LSD) where differences with $\mathrm{P}<0.05$ were considered significant. Where appropriate, data were analysed by exponential regression analysis according to the following model $\mathrm{Y}=\mathrm{a}+\mathrm{b} \times\left(1-\mathrm{d}^{\left(-\mathrm{c}^{*} \mathrm{X}\right)}\right)$, where: $\mathrm{Y}$ - performance of the animals, $\mathrm{a}$ - performance achieved with basal diet, $\mathrm{a}+\mathrm{b}$ - maximum performance, asymptote, $\mathrm{c}$ - steepness of the curve, $\mathrm{d}$ - amino acid level of the basal diet, and X - amino acid level.

\section{RESULTS AND DISCUSSION}

The birds responded significantly to increasing dietary methionine + cysteine levels (Table 1, Figure 1). The highest BWG (3621 g) reached turkeys from group 6 and this value was close to BUT (2000) recommendation (3760 g). The response was of a non-linear nature but exponential regression analysis revealed that the asymptote or maximum performance was not achieved with the highest met + cyst level (Figure 1). 
Table 1. Responses of Big 6 turkey toms to graded levels of dietary methionine and cysteine

\begin{tabular}{|c|c|c|c|c|c|c|}
\hline \multirow[t]{2}{*}{ Group } & \multicolumn{2}{|c|}{$\begin{array}{c}\text { Dietary } \\
\text { methionine+cysteine }\end{array}$} & \multirow{2}{*}{$\begin{array}{l}\text { Weight gain } \\
\mathrm{g}\end{array}$} & \multirow{2}{*}{$\begin{array}{c}\text { Feed intake } \\
\mathrm{g}\end{array}$} & \multirow{2}{*}{$\begin{array}{c}\text { Feed per gain } \\
\mathrm{kg} / \mathrm{kg}\end{array}$} & \multirow{2}{*}{$\begin{array}{l}\text { Nitrogen } \\
\text { retention } \\
\mathrm{g} / \mathrm{d}\end{array}$} \\
\hline & $\mathrm{g} / \mathrm{kg}$ & $\mathrm{g} / \mathrm{MJ} \mathrm{ME}$ & & & & \\
\hline 1 & 7.5 & 0.607 & $3274^{\mathrm{c}}$ & $6699^{c}$ & 2.047 & 5.19 \\
\hline 2 & 7.9 & 0.639 & $3406^{\mathrm{bc}}$ & $6813^{b c}$ & 2.003 & 5.26 \\
\hline 3 & 8.3 & 0.672 & $3479^{\mathrm{ab}}$ & $7042^{\mathrm{abc}}$ & 2.025 & 5.54 \\
\hline 4 & 8.8 & 0.712 & $3539^{\mathrm{ab}}$ & $7056^{\mathrm{abc}}$ & 2.005 & 5.36 \\
\hline 5 & 9.3 & 0.752 & $3568^{\mathrm{ab}}$ & $7250^{\mathrm{ab}}$ & 2.054 & 5.60 \\
\hline 6 & 9.9 & 0.801 & $3621^{a}$ & $7400^{a}$ & 2.046 & 5.57 \\
\hline SEM & & & 27 & 74 & 0.019 & 0.12 \\
\hline
\end{tabular}

Taking $95 \%$ of the asymptotic response as optimum performance, the corresponding methionine + cysteine level would be $0.85 \mathrm{~g} / \mathrm{MJ} \mathrm{ME}$ and thus 0.05 $\mathrm{g} / \mathrm{MJ}$ ME higher than the highest tested level. This is very much in line with the current Degussa recommendation (2002) giving an optimum level of $0.86 \mathrm{~g} / \mathrm{MJ}$ ME but much higher than values given by GfE (2004), $0.63 \mathrm{~g} / \mathrm{MJ}$ ME; NRC (1994), $0.78 \mathrm{~g} / \mathrm{MJ}$ ME or Faruga and Jankowski (1996), $0.81 \mathrm{~g} / \mathrm{MJ}$ ME and lower than recommendations by BUT (2000), $0.94 \mathrm{~g} / \mathrm{MJ}$ ME.

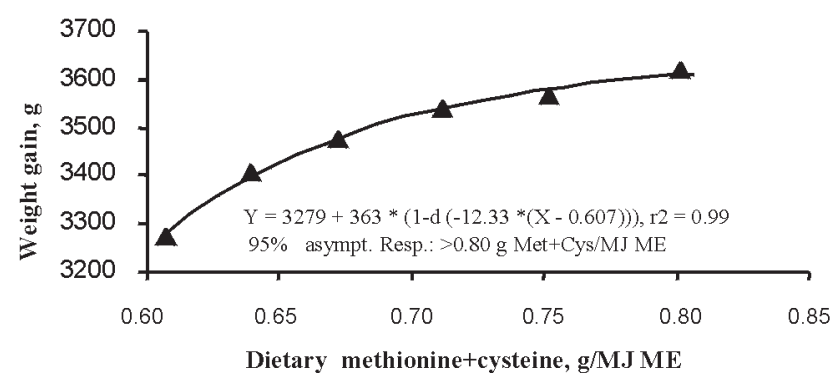

Figure 1. Response of turkeys to graded levels of dietary methionine+cysteine

FCR was almost not affected due to increasing feed intake with increasing dietary methionine+cysteine level (Table 1). This is in contrast to observations of Moore et al. (2004) reporting non-linear improvement in both BWG and FCR in 47-56-day-old turkey toms. However, in that study growth performance was much lower than could be expected with respect to BUT (2000) performance goals. In addition, FCR ranged between 2.63 and 2.00, while in the present study it was always close to the average of 2.03. Schutte et al. (1986) also observed non-linear responses in male and female BUT Big 6 turkeys in highest achieved weight gain that was about $30 \%$ (1000 g) lower compared with the current trial. Our data for both performance parameters suggested an optimum methionine + cysteine 
level higher than $0.83 \mathrm{~g} / \mathrm{MJ} \mathrm{ME}$. Table 1 shows the nitrogen retention of the turkeys. The data are much more varied compared with the BWG data but indicate at least a trend that the amount of retained nitrogen increased with increasing methionine+cysteine provision. This trend confirms the findings in weight gain. Similarly to FCR, nitrogen utilization (retention in $\%$ of N-intake) was also not affected.

\section{CONCLUSIONS}

The response in body weight gain suggested optimum dietary methionine + cysteine levels higher than $0.80 \mathrm{~g} / \mathrm{MJ} \mathrm{ME}$, while feed conversion was not affected.

\section{REFERENCES}

BUT (British United Turkeys Limited), 2000. BUT Performance Goals. British United Turkeys Limited, Broughton, Chester

Degussa, 2002. Total amino acids and true fecal digestible amino acids for broilers, turkeys and laying hens. Degussa AG, Feed Additives, Hanau

GfE (Society of Nutrition Physiology), 2004. Empfehlungen zur Energie- und Nährstoffversorgung der Mastputen. Proc. Soc. Nutr. Physiol. 13, 199-233

Faruga A., Jankowski J., 1996. Nutrient requirements of turkeys. In: S. Smulikowska (Editor). Nutrient Requirements of Poultry (in Polish). The Kielanowski Institute of Animal Physiology and Nutrition PAS, Jabłonna (Poland), pp. 56-68

Moore D.T., Baker K., Thompson K., Blair E., Firman J.D., 2004. Digestible sulphur amino acid requirement for male turkeys from six to twelve weeks of age. J. Appl. Poultry Res. 13, 155162

NRC (National Research Council), 1994. Nutrient Requirements of Poultry. $9^{\text {th }}$ revised Edition. National Academy Press, Washington

Schutte J.B., van Weerden E.J., Bertram H.L., 1986. Sulphur amino acid requirement of young turkeys. Proceedings of $7^{\text {th }}$ European Poultry Conference, Paris, pp. 369-372

\section{STRESZCZENIE}

Reakcja indorów w okresie od 36. do 63. dnia życia na wzrastającą zawartość metioniny+ cysteiny w mieszance

Do badań użyto 734 indory BUT Big 6 w wieku 36 dni. W 6 grupach doświadczalnych, każda w 6 powtórzeniach, podawano mieszanki z różnym dodatkiem metioniny, odpowiednio $0,0,4 ; 0,8$; 1,$3 ; 1,8$ i $2,4 \mathrm{~g} / \mathrm{kg}$. W ciagu 4 tygodni doświadczenia przyrosty masy ciała indorów były proporcjonalne do dodatku metioniny do mieszanek i zgodne $\mathrm{z}$ równaniem regresji nie liniowej $\mathrm{Y}=3279$ $+363 \times\left(1-\mathrm{d}^{(-12.33 \times(\mathrm{X}-0.607))}\right), \mathrm{r}^{2}=0.99$. Retencja azotu u indyków wzrastała wraz ze zwiększaniem zawartości metioniny+cysteiny $\mathrm{w}$ mieszance. Wzrastające przyrosty masy ciała indorów, przy zbliżonym wykorzystaniu paszy sugerują, że optymalny poziom metioniny+ cysteiny w mieszance powinien być wyższy niż $0,80 \mathrm{~g} / \mathrm{MJ}$ energii metabolicznej. 